\title{
Investigation of the Complex Influence of High- and Low-Molecular Glutenins and Crude Protein on the Quality of Bread Wheat (T. aestivum L.)
}

\author{
Sonya Doneva ${ }^{1 *}$, Margarita Nankova ${ }^{1}$ and Stefan Krustev ${ }^{2}$ \\ ${ }^{1}$ Dobrudzha Agricultural Institute, General Toshevo, Bulgaria \\ ${ }^{2}$ Agricultural University, Plovdiv, Bulgaria \\ *Corresponding Author: Sonya Doneva, Dobrudzha Agricultural Institute, \\ General Toshevo, Bulgaria.
}

Received: April 01, 2020

Published: July 01, 2020

(C) All rights are reserved by Sonya Doneva.,

et al.

\begin{abstract}
The relation between high- (HMW) and low-molecular (LMW) glutenins with the quality indicators - sedimentation value, valorimetric value and bread loaf of a collection of Bulgarian wheat varieties was studied.

A total of about $63 \%$ of the sedimentation value, $44 \%$ of the valorimetric value and $39 \%$ of the bread loaf was controlled by the two groups of glutenins and the crude protein.

The high-and low-molecular weight glutenins had an almost equal share in controlling the sedimentation value and the valorimetric value. The LMW glutenins had a significantly higher share in controlling bread loaf than that of HMW glutenins.

The participation of individual glutenin loci in quality control was not one-sided. It was mainly determined by genetic diversity and by the linking with the quality of the individual glutenin subunits.

The relative contribution of crude protein to the control of quality indicators during the various harvest years was highly variable, but its optimum quantity was a necessary condition for showing the positive effect of glutenin subunits on the quality of the wheat varieties.
\end{abstract}

Keywords: Winter Wheat; HMW- and LMW-Glutenins; Crude Protein; Sedimentation Value; Valorimetric Value; Bread Loaf

\section{Introduction}

The reserve proteins accumulated in the grain of wheat are the main components of gluten and are essential for determining the properties of dough and bread. They are subdivided into two groups - gliadins and glutenins and differ in their genetic condition and functional properties [37]. Gliadins mainly determine the stretch ability of wheat gluten [25]. The elasticity/strength of gluten is mainly determined by glutenins $[7,8,21,23]$. A characteristic feature of the genetic control of reserve proteins is the multiple allelism, which is the hereditary basis of their polymorphic structure and different alleles determine the expression of different protein subunits. Since each subunit is associated with a different quality of wheat gluten, there is a great variety in terms of baking qualities $[1,4,15,17]$. The specific features of the reserve proteins underlie their use as genetic markers to determine the hereditary quality potential of different wheat samples. The complex effect of prolamines and in particular high- and low-molecular gluten, on wheat quality is most pronounced in their ability to form together polymers of enormous molecular weight in the order of millions of daltons, on which the strength of wheat gluten depends $[5,6,27]$. The results of the studies of $[18,32,35,36]$, show that the effect of allelic variation in gluten on quality is different depending on the 
amount of protein in the wheat lines studied. These facts justify the need for study of the complex influence of high- and low-molecular glutenins and raw protein on wheat quality $[9,10,14]$.

This article examines the results of a linkage study of some qualitative indicators - sedimentation value, valorimetric value and bread loaf with HMW and LMW alleles from the six Glu1 and Glu3 loci and the amount of crude protein.

\section{Materials and Methods}

\section{Materials}

34 varieties of common wheat (T. aestivum L., $2 \mathrm{n}=28$ ) breeding in Dobrudzha Agricultural Institute (Bulgaria) during the period 2009-2016, were studied: Todora, Bozhana, Aglika, Stoyana, Milena, Rada, Karat, Kristi, Antonovka, Karina, Korona, Kosara, Neda, Bolyarka, Lazarka, Demetra, Goritsa, Zhana, Kristalina, Laska, Fani, Merilin, Galateya, Sladuna, Kalina, Katarzhina, Enola, Kami, Kiara, Kristal, Dragana, Iveta, Pchelina, Tina.

\section{Methods}

Electrophoretic methods: Glutenins (HMW- and LMW-GS) were extracted according to [34]. The electrophoresis run on vertical apparatus in two ways: a) classical one-dimensional $12 \%$ polyacrylamide gel [20]; b) one-dimensional $10 \%$ polyacrylamide gel SDS-PAGE with addition of 4M urea [19]. Arrangement and numbering of HMW-GS in wheat was carried out according [30]. LMWGS nomenclature in wheat [11] and combined method for LMW-GS and gliadin identification were adopted [16].

Technological methods: The grinding of the samples was carried out on a mill MLU-202 up to 70\% flour. The sedimentation value of the wheat samples was determined by the method of [33], the rheological properties of the flour-the stability of the dough, the degree of softening and the valorimetric value and the bread loaf-according to the methods adopted in the technological laboratory of Dobrudzha Agricultural Institute, Bulgaria Crude protein content (\%) was determined by standard Kjeldahl method (N x 7.5) [2].

\section{Statistical analysis}

Multiple correlation analysis [3] of STATISTICA package was performed for statistical data processing. The Glu-1 and Glu-3 alleles and the amount of crude protein were used as independent variables $(\mathrm{X})$ and each of the above qualitative attributes was used as the dependent variable (Y). For this purpose, the high- and low-molecular-weight glutenin alleles were transformed into the numbers 1 and 0 , which means, respectively, the presence and absence of an allele in the analyzed wheat sample. The indicator of genetic diversity - $\mathrm{H}$ at individual glutenin loci was determined by the method of [13]. As a result of the above statistical analysis, the following indicators have been identified: $\mathrm{R}$ is a multiple correlation coefficient expressing the degree of relationship between the independent variables $(\mathrm{X})$ and the dependent variable $(\mathrm{Y}) . \mathrm{R}^{2}$ - multiple determination coefficient, expressed as a percentage, indicates how much of the value of the dependent variable $(\mathrm{Y})$ is determined by the corresponding independent variables $(X)$. SEstandard error of estimation (prediction) reflecting the average difference between the true and predicted values of the dependent variable $(\mathrm{Y})$.

\section{Results}

Allelic composition of HMW and LMW of the analyzed wheat varieties

The HMW allelic composition of the analyzed wheat samples is presented in table 1.

\begin{tabular}{|l|c|c|c|c|}
\hline \multicolumn{1}{|c|}{ Locus } & Alleles & Subunits & $\begin{array}{c}\text { Number of } \\
\text { varieties }\end{array}$ & Frequency, \% \\
\hline Glu- $A 1$ & $a$ & 1 & 10 & 26.3 \\
$\mathrm{H}^{*}=0.60$ & $b c$ & $2^{*}$ & 17 & 44.7 \\
& & Null & 11 & 29.0 \\
\hline Glu-B1 & $b$ & $7+8$ & 15 & 39.5 \\
H $=0.52$ & $c$ & $7+9$ & 23 & 60.5 \\
\hline Glu-D1 & $a$ & $2+12$ & 5 & 13.2 \\
H $=0.27$ & $b$ & $3+12$ & 1 & 2.6 \\
\hline Glu-1 & $d$ & $5+10$ & 32 & 84.2 \\
H $=0.46$ & \multicolumn{4}{|l}{} \\
\hline
\end{tabular}

Table 1: HMW glutenins composition in Glu-1 locus of wheat varieties during the period 2000-2016 (including two biotypes for the Laska variety, two for the Galateya variety and three for the Sladuna variety). H-Genetic diversity index $[13,26]$.

The Glu-A1 locus was characterized by a relatively high genetic diversity, $\mathrm{H}=0.65$. Its inherited potential is formed by three alleles - Glu-A1 $a$, Glu-A1 $b$ and Glu-A1c. The ' 2 *' subunit (allel ' $b$ '), associated with high gluten quality, has the highest frequency $(44.7 \%)$. 
Subunit 'null' (allel ' $c$ ') is next in frequency (29.0\%). It is characterized by zero protein synthesis and results in low baking properties. Subunit ' 1 ' (allel ' $a$ ') has the lowest frequency - 26.3\%.

Although the allelic diversity at the Glu-B1 locus of T. aestivum is very large, only two alleles were identified in the present study (Table 1). The genetic diversity of the locus is at an average level - $\mathrm{H}=0.52$. This is a result of the high frequency of the allele ' $c$ ' $(60.5 \%)$ and the low frequency of the allele ' $b$ ' (39.5\%).

Three alleles encoding the ' $5+10$ ', ' $2+12$ ' and ' $3+12$ ' fraction pairs were identified at the Glu-D1 locus. The ' $5+10$ ' fractional pair has a high frequency, resulting in relatively low genetic diversity at the locus. The atypical fraction pair ' $3+12$ ' is characteristic of only the two Fani biotypes. It is thought to be a mutant form of the ' $x$-' and ' $y$-' subunits of the main fraction pair ' $2+12$ ' $[19,24,35]$.

In general, the hereditary basis for the quality of the analyzed wheat samples, controlled by HMW, has an average level of genetic diversity -0.46 .

The LMW allelic composition of the analyzed wheat samples is presented in table 2 .

\begin{tabular}{|l|c|c|c|}
\hline \multicolumn{1}{|c|}{ Locus } & Alleles & Number of varieties & Frequency, \% \\
\hline Glu- 3 & $c$ & 29 & 72.5 \\
$\mathrm{H}^{*}=0.45$ & $f$ & 1 & 2.5 \\
& $b$ & 1 & 2.5 \\
& $e$ & 6 & 15.0 \\
& $d$ & 3 & 7.5 \\
\hline Glu-B3 & $b$ & 24 & 60.0 \\
H = 0.59 & $f$ & 3 & 7.5 \\
& $g$ & 3 & 5.0 \\
& $h$ & 8 & 7.5 \\
& $j$ & 35 & 20.0 \\
\hline Glu-D3 & $c$ & 5 & 87.5 \\
H $=0.22$ & $a$ & & 12.5 \\
\hline Glu-3 & & & \\
H $=0.42$ & & 35 & \\
\hline
\end{tabular}

Table 2: LMW glutenins composition in Glu-3 locus of wheat varieties during the period 2000-2016 (including two biotypes for the Laska variety, two for the Galateya variety, two for the Tina variety and three for the Sladuna variety).

$\mathrm{H}-$ Genetic diversity index $[13,26]$.
Five alleles have been identified at the Glu-A3 locus. The major allele is ' $c$ ', with a frequency of $68.3 \%$, respectively. The other alleles have a low frequency.

A significantly higher value of the genetic diversity index was observed at the Glu-B3 locus, in which five alleles were also identified. The main allele is ' $b$ ' and the other four alleles have a low frequency.

Only two alleles were identified at the Glu-D3 locus - ' $c$ ' and ' $a$ '.

The high frequency of the 'c' allele is the reason for the relatively low genetic diversity at this locus.

Generally, in the analyzed wheat varieties analyzed, LMW have a much lower genetic diversity than HMW.

Multiple correlation of HMW, LMW and crude protein with some qualitative features

HMW, LMW and crude protein/sedimentation

Table 3 presents the results regarding the complex effect of high- and low-molecular-weight glutenin subunits and crude protein on the sedimentation value of the analyzed wheat varieties.

\begin{tabular}{|l|c|c|c|c|}
\hline Year & $\mathbf{R}$ & F-criterion & $\mathbf{S E}$ & $\mathbf{R}^{2}$ \\
\hline 2009 & 0.77 & $12.04^{* * *}$ & 5.21 & 0.60 \\
\hline 2010 & 0.79 & $14.18^{* * *}$ & 6.15 & 0.62 \\
\hline 2011 & 0.80 & $18.74^{* * *}$ & 10.33 & 0.65 \\
\hline 2012 & 0.79 & $16.45^{* * *}$ & 16.45 & 0.63 \\
\hline 2013 & 0.91 & $6.67^{* * *}$ & 6.38 & 0.82 \\
\hline 2014 & 0.89 & $12.03^{* * *}$ & 4.15 & 0.79 \\
\hline 2015 & 0.82 & $13.25^{* * *}$ & 7.08 & 0.67 \\
\hline 2016 & 0.55 & $4.40^{* * *}$ & 8.94 & 0.31 \\
\hline
\end{tabular}

Table 3: Multiple correlation coefficient reflecting the relationship of HMW, LMW and the content of crude protein with the sedimentation value of wheat varieties.

$$
* * * \mathrm{P}<0.001 \text {. }
$$

The values of the multiple correlation coefficient $\mathrm{R}$ (from 0.55 to $0.91)$ and the high degree of proof of criterion $F(P<0.001)$ are indicative of the presence of a well-expressed complex relationship of HMW, LMW and crude protein with sedimentation value. The multiple determination coefficients $\mathrm{R}^{2}(\%)$ indicate that 60 to $82 \%$ (ex- 
cluding 2016) of variation in the sedimentation value of the analyzed wheat samples is due to the high- and low-molecular-weight glutenin alleles and the crude protein. On average over the period 2009-2016, HMW (Glu-1) controlled 21.99\% of the variation in the sedimentation value of wheat samples. In all years, a significant share of this control is attributed to the Glu-A1 and Glu-B1 loci and less to the Glu-D1 locus (2.65\%). LMW (Glu-3) accounted for $29.78 \%$ of the sedimentation. According to the effect on this trait the LMW loci are arranged in the following order: Glu-B3 > Glu-A3 $>$ Glu-D3 during the analyzed period (Table 4).

During the study period HMW + LMW are responsible for $51.77 \%$ of the variation in sedimentation, and when added to the influence of the crude protein, this percentage increases to 63.75 . The rest (36.25\%) of the sedimentation control is due to other factors (Table 4).

\begin{tabular}{|c|c|c|c|c|c|c|c|c|c|c|c|c|}
\hline \multirow{2}{*}{ Year } & \multicolumn{4}{|c|}{ HMW } & \multicolumn{4}{|c|}{ LMW } & \multirow{2}{*}{$\begin{array}{c}\text { HMW+ } \\
\text { LMW }\end{array}$} & \multirow{2}{*}{ Protein } & \multirow{2}{*}{$\begin{array}{c}\text { Glu+ } \\
\text { Protein }\end{array}$} & \multirow{2}{*}{ Others } \\
\hline & Glu A1 & Glu B1 & Glu D1 & Glu 1 & Glu A3 & Glu B3 & Glu D3 & Glu3 & & & & \\
\hline 2009 & $7.62^{\mathrm{b}}$ & $5.63^{b}$ & 4.86 & $18.11^{\mathrm{c}}$ & $7.47^{\mathrm{b}}$ & $13.71^{\mathrm{c}}$ & 1.67 & $22.85^{\mathrm{c}}$ & $40.95^{\mathrm{c}}$ & $18.85^{c}$ & $59.80^{c}$ & 40.20 \\
\hline 2010 & $7.37^{c}$ & $5.93^{c}$ & $5.13^{a}$ & $18.43^{c}$ & $14.29^{c}$ & $8.09^{a}$ & 2.04 & $24.42^{\mathrm{c}}$ & $42.85^{c}$ & $19.05^{c}$ & $61.90^{c}$ & 38.10 \\
\hline 2011 & $13.1^{c}$ & $7.03^{c}$ & $3.53^{\mathrm{b}}$ & $23.65^{c}$ & $7.27^{\mathrm{c}}$ & $9.66^{c}$ & $9.75^{c}$ & $26.68^{c}$ & $50.33^{c}$ & $14.47^{\mathrm{c}}$ & $64.80^{c}$ & 35.20 \\
\hline 2012 & $14.70^{c}$ & $6.87^{c}$ & $3.56^{\mathrm{b}}$ & $25.13^{c}$ & $6.57^{c}$ & $11.64^{\mathrm{c}}$ & $10.43^{\mathrm{c}}$ & $28.63^{c}$ & $53.76^{c}$ & $9.33^{\mathrm{c}}$ & $63.09^{c}$ & 36.90 \\
\hline 2013 & $16.64^{\mathrm{a}}$ & $15.05^{\mathrm{a}}$ & 2.51 & 34.2 & 8.30 & $23.58^{\mathrm{b}}$ & 2.33 & $34.21^{\mathrm{b}}$ & $68.41^{c}$ & $13.70^{\mathrm{a}}$ & $82.11^{\mathrm{c}}$ & 17.89 \\
\hline 2014 & $8.89^{a}$ & $24.41^{\mathrm{c}}$ & 0.00 & $33.3^{c}$ & $12.19^{\mathrm{a}}$ & $17.65^{c}$ & $4.87^{\mathrm{a}}$ & $34.71^{\mathrm{c}}$ & $68.01^{c}$ & $11.49^{\mathrm{a}}$ & $79.50^{c}$ & 20.50 \\
\hline 2015 & $5.08^{\mathrm{c}}$ & $2.82^{\mathrm{a}}$ & 1.60 & $9.50^{\mathrm{c}}$ & $14.56^{\mathrm{b}}$ & $38.46^{c}$ & 3.29 & $56.31^{\mathrm{c}}$ & $65.81^{c}$ & 1.69 & $67.50^{c}$ & 32.50 \\
\hline 2016 & $12.95^{\mathrm{b}}$ & 0.67 & 0.00 & $13.62^{\mathrm{b}}$ & $6.86^{\mathrm{b}}$ & 2.26 & 1.26 & $10.38^{\mathrm{a}}$ & $24.00^{\mathrm{b}}$ & $7.30^{\mathrm{b}}$ & $31.30^{c}$ & 68.70 \\
\hline Average & 10.79 & 8.55 & 2.65 & 21.99 & 9.69 & 15.63 & 4.46 & 29.40 & 51.77 & 11.99 & 63.75 & 36.25 \\
\hline
\end{tabular}

Table 4: Proportion of HMW, LMW and crude protein in the formation of the sediment value of wheat varieties - 2009-2016. $\mathrm{a}, \mathrm{b}, \mathrm{c}=$ Proof of the correlations at $\mathrm{P}<0.05 ; 0.01 ; 0.001$ respectively.

HMW, LMW and crude protein/valorimetric value

The multiple correlation coefficients expressing the complex relationship of HMW, LMW and crude protein with the valorimetric value of wheat samples have very good statistical evidence (Table 5).

\begin{tabular}{|l|c|c|c|c|}
\hline Year & $\mathbf{R}$ & F-criterion & $\mathbf{S E}$ & $\mathbf{R}^{\mathbf{2}}$ \\
\hline 2009 & 0.62 & $5.73^{* * *}$ & 6.56 & 0.39 \\
\hline 2010 & 0.65 & $7.84^{* * *}$ & 4.64 & 0.42 \\
\hline 2011 & 0.75 & $13.06^{* * *}$ & 9.94 & 0.56 \\
\hline 2012 & 0.65 & $6.40^{* * *}$ & 13.68 & 0.43 \\
\hline 2013 & 0.86 & $8.37^{* * *}$ & 6.45 & 0.75 \\
\hline 2014 & 0.62 & $3.10^{* *}$ & 8.38 & 0.39 \\
\hline 2015 & 0.64 & $5.98^{* * *}$ & 10.17 & 0.41 \\
\hline 2016 & 0.52 & $4.79^{* * *}$ & 8.28 & 0.27 \\
\hline
\end{tabular}

Table 5: Multiple correlation coefficient reflecting the relationship of HMW, LMW and the content of crude protein with valorimetric value of wheat varieties.

$$
\text { ** } \mathrm{P}<0.01,{ }^{* * *} \mathrm{P}<0.001 \text {. }
$$

Their values range from average in 2016 to high in 2013. This also reflects on the multiple determination coefficients $-\mathrm{R}^{2}$. Apparently, the years have a certain effect on the interconnections between the biochemical and technological parameters studied.

It was found that on average for the period 2009 - 2016, HMW and LMW control a total of $35.57 \%$ of the variation in the valorimetric value of wheat samples. With the inclusion of crude protein this percentage increased to 45.15 . HMW account for $16.48 \%$ of the value of the valorimetric index. In the individual years, there is no unidirectionality in the ordering of the three Glu-1 loci, but the GluA1 and Glu-B1 loci have a significant influence on the indicator over the study period and to a lesser extent Glu-D1 locus (Table 6).

HMW control $19.09 \%$ of the valorimetric value. Glu-A3 and Glu-B3 loci account for a significant proportion of this control. The influence of Glu-D3 is weak and insignificant in some years. The control of the other factors is significant - $54.85 \%$ (Table 6). 


\begin{tabular}{|l|c|c|c|c|c|c|c|c|c|c|c|c|}
\hline \multirow{2}{*}{ Year } & \multicolumn{5}{|c|}{ HMW } & \multicolumn{5}{c|}{ LMW } & HMW+ \\
& \cline { 2 - 13 } & Glu A1 & Glu B1 & Glu D1 & Glu 1 & Glu A3 & Glu B3 & Glu D3 & Glu 3 & Protein & $\begin{array}{c}\text { Glu+ } \\
\text { Protein }\end{array}$ & Others \\
\hline 2009 & $6.32^{\mathrm{b}}$ & $4.42^{\mathrm{b}}$ & 4.01 & $14.75^{\mathrm{c}}$ & $12.62^{\mathrm{c}}$ & 3.48 & 1.91 & $18.01^{\mathrm{c}}$ & $32.76^{\mathrm{c}}$ & $5.84^{\mathrm{a}}$ & $38.60^{\mathrm{c}}$ & 61.40 \\
\hline 2010 & 0.51 & $2.38^{\mathrm{a}}$ & $5.79^{\mathrm{b}}$ & $8.68^{\mathrm{b}}$ & $4.39^{\mathrm{a}}$ & $6.31^{\mathrm{a}}$ & 0.48 & $11.18^{\mathrm{b}}$ & $19.86^{\mathrm{c}}$ & $22.04^{\mathrm{c}}$ & $41.90^{\mathrm{c}}$ & 58.10 \\
\hline 2011 & $11.12^{\mathrm{c}}$ & $6.12^{\mathrm{c}}$ & $5.11^{\mathrm{c}}$ & $22.35^{\mathrm{c}}$ & $8.68^{\mathrm{c}}$ & $5.28^{\mathrm{c}}$ & $7.68^{\mathrm{c}}$ & $21.64^{\mathrm{c}}$ & $43.99^{\mathrm{c}}$ & $12.21^{\mathrm{c}}$ & $56.20^{\mathrm{c}}$ & 43.80 \\
\hline 2012 & $12.10^{\mathrm{c}}$ & $3.28^{\mathrm{b}}$ & 1.10 & $16.48^{\mathrm{c}}$ & $4.26^{\mathrm{b}}$ & $7.12^{\mathrm{c}}$ & $6.63^{\mathrm{c}}$ & $18.01^{\mathrm{c}}$ & $34.49^{\mathrm{c}}$ & $8.11^{\mathrm{b}}$ & $42.60^{\mathrm{c}}$ & 57.40 \\
\hline 2013 & 2.56 & $33.14^{\mathrm{c}}$ & 1.77 & $37.47^{\mathrm{b}}$ & $19.45^{\mathrm{b}}$ & 12.58 & 2.34 & $34.37^{\mathrm{b}}$ & $71.84^{\mathrm{c}}$ & 2.66 & $74.50^{\mathrm{c}}$ & 25.50 \\
\hline 2014 & 0.98 & 3.76 & 1.05 & 5.79 & 12.18 & 8.57 & 0.00 & 20.75 & 26.54 & $12.46^{\mathrm{b}}$ & $39.00^{\mathrm{b}}$ & 61.00 \\
\hline 2015 & $6.28^{\mathrm{b}}$ & $6.91^{\mathrm{b}}$ & 0.92 & $14.11^{\mathrm{c}}$ & $6.15^{\mathrm{a}}$ & $12.2^{\mathrm{b}}$ & 0.00 & $18.35^{\mathrm{b}}$ & $32.46^{\mathrm{c}}$ & $8.54^{\mathrm{b}}$ & $41.00^{\mathrm{c}}$ & 59.00 \\
\hline 2016 & $3.95^{\mathrm{b}}$ & $5.36^{\mathrm{b}}$ & 2.86 & $12.17^{\mathrm{c}}$ & 3.15 & $6.51^{\mathrm{b}}$ & 0.74 & $10.40^{\mathrm{b}}$ & $22.57^{\mathrm{c}}$ & $4.83^{\mathrm{a}}$ & $27.40^{\mathrm{c}}$ & 72.60 \\
\hline Average & 5.48 & 8.17 & 2.83 & 16.48 & 8.86 & 7.76 & 2.47 & 19.09 & 35.56 & 9.59 & 45.15 & 54.85 \\
\hline
\end{tabular}

Table 6: Proportion of HMW, LMW and crude protein in the formation of the valorimetric value of wheat varieties - 2009-2016.

$$
\mathrm{a}, \mathrm{b}, \mathrm{c}=\text { Proof of the correlations at } \mathrm{P}<0.05 ; 0.01 ; 0.001 \text { respectively. }
$$

\section{HMW, LMW and crude protein/bread loaf}

The multiple correlation coefficients (Table 7) expressing the complex relationship of HMW, LMW and crude protein with the bread loaf have very good statistical evidence $(\mathrm{R}=0.46-0.85, \mathrm{~F}=$ $2.99^{* *}-7.24^{* * *}$ ). Over the years, there is a well-defined complex relationship (R) between the glutenins and the crude protein on the one hand and bread loaf on the other hand which ranged from $\mathrm{R}=0.46$ in 2015 to $\mathrm{R}=0.85$ in 2013 .

\begin{tabular}{|c|c|c|c|c|}
\hline Year & R & F-criterion & SE & R2 \\
\hline 2009 & 0.66 & $6.24^{* * *}$ & 53.91 & 0.43 \\
\hline 2010 & 0.62 & $5.39^{* * *}$ & 34.08 & 0.38 \\
\hline 2011 & 0.64 & $7.06^{* * *}$ & 46.10 & 0.41 \\
\hline 2012 & 0.57 & $5.91^{* * *}$ & 46.15 & 0.32 \\
\hline 2013 & 0.85 & $7.24^{* * *}$ & 44.27 & 0.72 \\
\hline 2014 & 0.62 & $3.06^{* *}$ & 47.57 & 0.39 \\
\hline 2015 & 0.46 & $2.99^{* *}$ & 52.83 & 0.21 \\
\hline 2016 & 0.52 & $5.69^{* * *}$ & 49.33 & 0.27 \\
\hline
\end{tabular}

Table 7: Multiple correlation coefficient reflecting the relationship of HMW, LMW and the content of crude protein with bread volume of wheat samples.$$
\text { ** } \mathrm{P}<0.01,{ }^{* * *} \mathrm{P}<0.001 \text {. }
$$

However, in some years this correlation is manifested to a much lower extent due to the strong influence of other factors on this indicator (60.7\%) (Table 8).
For the study period, LMW, HMW, and crude protein controlled $39.30 \%$ of the variation in bread loaf. In 2013, when control of the other factors was lowered, HMW + LMW + crude protein $(71.7 \%)$ had a significant impact on the bread loaf (Table 8). Unlike sedimentation and valorimetric value, the proportion of LMW is significantly higher $-22.26 \%$, compared to $9.91 \%$ for HMW. This finding is one-way for all years 2009 - 2016.

\section{Discussion}

In the present study, it was found that HMW and LMW had almost the same share in controlling the main indicators related to gluten strength - sedimentation value and valorimetric value. Similar equivalence of the two glutenin groups in the sedimentation control and other qualitative indicators are also indicated by $[22,28]$. The association of these proteins with quality indicators is determined mainly by their molecular weight and by the ability of their subunits to participate in the polymerization process, which plays a major role in the formation of gluten with good physical properties [12,38]. HMW have an advantage in this regard [29].

The higher ability of high molecular weight subunits to form polymers is due to their structure.

On the other hand, the amount of storage proteins is of great importance for their effect on gluten strength. As mentioned, LMW have roughly the same proportion with HMW in controlling the basic qualitative indicators (sedimentation and valorimetric 


\begin{tabular}{|c|c|c|c|c|c|c|c|c|c|c|c|c|}
\hline \multirow{2}{*}{ Year } & \multicolumn{4}{|c|}{ HMW } & \multicolumn{4}{|c|}{ LMW } & \multirow{2}{*}{$\begin{array}{c}\text { HMW+ } \\
\text { LMW }\end{array}$} & \multirow{2}{*}{ Protein } & \multirow{2}{*}{$\begin{array}{c}\text { Glu+ } \\
\text { Protein }\end{array}$} & \multirow{2}{*}{ Others } \\
\hline & Glu A1 & Glu B1 & Glu D1 & Glu 1 & Glu A3 & Glu B3 & Glu D3 & Glu 3 & & & & \\
\hline 2009 & 2.32 & 1.21 & 1.72 & 5.25 & $12.06^{c}$ & $10.53^{\mathrm{a}}$ & $3.66^{\mathrm{a}}$ & $26.25^{c}$ & 31.50 & $12.00^{c}$ & $43.50^{c}$ & 56.50 \\
\hline 2010 & 2.08 & 0.84 & $7.08^{\mathrm{a}}$ & $10.00^{\mathrm{a}}$ & $10.37^{c}$ & $5.66^{\mathrm{a}}$ & 0.00 & $16.03^{b}$ & $26.03^{c}$ & $12.17^{\mathrm{c}}$ & $38.20^{c}$ & 61.80 \\
\hline 2011 & $4.86^{\mathrm{b}}$ & $2.05^{\mathrm{a}}$ & $2.76^{\mathrm{a}}$ & $9.67^{b}$ & $4.67^{\mathrm{b}}$ & $9.33^{c}$ & $5.05^{c}$ & $19.05^{c}$ & $28.72^{c}$ & $12.18^{\mathrm{c}}$ & $40.90^{c}$ & 59.10 \\
\hline 2012 & 7.24 & 0.69 & 1.03 & 8.96 & 6.98 & 7.82 & 3.36 & 18.16 & 27.12 & $5.48^{\mathrm{b}}$ & 32.60 & 67.40 \\
\hline 2013 & $20.16^{\mathrm{a}}$ & 9.24 & 0.00 & $29.4^{\mathrm{a}}$ & 4.21 & $35.49^{\mathrm{b}}$ & 0.00 & $39.70^{\mathrm{b}}$ & $69.10^{c}$ & 2.60 & $71.70^{c}$ & 28.30 \\
\hline 2014 & 2.09 & $6.97^{a}$ & 0.00 & 9.06 & $13.08^{\mathrm{a}}$ & 1.66 & 3.31 & 18.05 & $27.11^{\mathrm{a}}$ & $11.59^{\mathrm{a}}$ & $38.70^{c}$ & 61.30 \\
\hline 2015 & 0.40 & 1.24 & 0.81 & 2.45 & 4.86 & 10.88 & 1.62 & $17.36^{\mathrm{a}}$ & $19.81^{a}$ & 1.52 & $21.33^{\mathrm{b}}$ & 78.70 \\
\hline 2016 & 0.00 & 0.00 & 3.99 & 3.99 & $4.33^{\mathrm{a}}$ & $19.18^{c}$ & 0.00 & $23.51^{\mathrm{c}}$ & $27.50^{c}$ & 0.00 & $27.50^{c}$ & 72.50 \\
\hline Average & 4.89 & 2.17 & 2.78 & 9.91 & 7.57 & 12.57 & 2.13 & 22.26 & 32.11 & 7.19 & 39.30 & 60.70 \\
\hline
\end{tabular}

Table 8: Proportion of HMW, LMW and crude protein in the formation of the bread loaf of wheat varieties - 2009-2016.

$\mathrm{a}, \mathrm{b}, \mathrm{c}=$ Proof of the correlations at $\mathrm{P}<0.05 ; 0.01 ; 0.001$ respectively.

value), despite the less favorable structure of their subunits for macropolymer formation. They compensate for this deficiency by about three times the amount with which they participate in the glutenin complex compared to HMW [12]. The results show that the involvement of the individual glutenin loci in the control of quality indicators is mainly determined by their genetic diversity. An example of this is the arrangement of HMW loci according to their effect on quality - Glu-A1 > Glu-B1 > Glu-D1. The locus with the highest genetic diversity, Glu-A1 $(\mathrm{H}=60)$ has the largest share in the control of the quality indicators. The locus with the lowest genetic diversity - Glu-D1 $(\mathrm{H}=0.27)$ had the least influence on the quality indicators. The genetic diversity, however, cannot be taken as an absolute indicator of the involvement of the relevant glutenin locus in quality control. It is known that a significant proportion of glutenin alleles are equivalent or similar in their effect on quality indicators, such as HMW alleles that determine the expression of subunits 1 and $2 *$ of the Glu A1 locus, at 7 and $6+8$, at $7+8$ and 17 + 18 from the Glu B1 locus and others [31].

Along with the glutenins, the amount of crude protein has a significant impact on the quality of the wheat varieties studied. Its relative involvement in quality control has been very variable over the years. A similar variation in the relative proportion by which the crude protein influences the different qualitative parameters is indicated by other authors $[22,36]$. In addition [18] state that the effect of varying HMW alleles depends on the amount of crude protein in the flour. The authors cited above found a difference in the bread loaf of wheat groups containing the opposite of their effect on the quality of the $5+10$ and $2+12$ fractional pairs at a protein content of 9.2 to $14 \%$. The $5+10$ fraction does not have a positive effect on quality beyond the specified limits.

The results of this study confirm the need for a comprehensive approach that, in addition to HMW glutenins, also includes the use of LMW glutenins as genetic markers, both in the evaluation of the source breeding material and in the breeding process. The optimal amount of crude protein is a necessary condition for the positive effect of glutenin subunits on the quality of wheat samples.

\section{Conclusion}

The results of the present study show that, by means of multiple correlations, a well-expressed complex association of glutenins and crude protein was established with some basic qualitative indicators.

HMW, LMW and crude protein control the following in total:

- About $64 \%$ of the sedimentation value, of which $52 \%$ from glutenins and $12 \%$ from crude protein;

- About $45 \%$ of the valorimetric value, of which $36 \%$ from glutenins and $9 \%$ from crude protein;

- About 39\% of the bread loaf, of which 32\% from glutenins and 7\% from crude protein. HMW and LMW have been found to have almost the same share in controlling the main indicators related to gluten strength - sedimentation value and valorimetric value. 


\section{Acknowledgements}

This paper is under the project "Investigation of selenium content in soils and wheat from main cereal production areas in Bulgaria" by the Ministry of Education and Science, Bulgaria.

\section{Bibliography}

1. Branland G., et al. "Genetic diversity of wheat storage proteins and bread making quality". Euphytica 119 (2001): 59-67.

2. Cohen J B. "Practical Organic Chemistry" (1910).

3. Cooley WW and Lohnes PR. "Multivariate data analysis". New York: Wiley (1971).

4. Dencic S and Vapa Lj. "Effect of intra and inter-allelic variation in Glu-A1 and Glu-D1 loci on bread-making quality in wheat". Cereal Research Communications 3 (1996): 317-322.

5. Dong H., et al. "High Molecular Weight Glutenin Genes: Effects on Quality in Wheat". Crop Science 31 (1991): 974-979.

6. D'Ovidio R and Masci S. "The low-molecular-weight glutenin subunits of wheat gluten". Journal of Cereal Chemistry 39 (2004): 321-339.

7. Gelder WMJ., et al. "The relationship between High-Molecular-Weight Glutenin Subunits, Bread-Making Quality and Yield of winter Wheat". Proceedings of the EU Preparatory Meeting (1987): 159-172.

8. Gianibelli M.C., et al. "Biochemical, Genetique, and Moleqular Characterization of Wheat Endosperm Proteins". Cereal Chemistry (2001): 1-20.

9. Groeger S., et al. "Quality and Quantity of HMW-Glutenin Subunits in Relation to Bread Making Quality of Austrian Winter Wheat Cultivars". Gluten 96, Proceedings of the Sixth International Gluten Workshop held in Sydney, $2^{\text {nd }}$ to $4^{\text {th }}$ September, 1996, in association with the $46^{\text {th }}$ Australian Cereal Chemistry Conference, edited by C.W. Wrigley, CSIRO Plant Industry and Quality Wheat CRC, North Ryde, NSW (1966): 43-47.

10. Gupta RB and Shepherd KW. "Low-molecular-weight glutenin subunits in wheat: their variation, inheritance and association with bread-making quality". Proceedings of $7^{\text {th }}$ International Wheat Genet. Symposium, Cambridge, UK (1988): 943-949.
11. Gupta RB and Shepherd KW. "Two-step one-dimensional SDSPAGE analysis of LMW subunits of glutenin". Theoretical and Applied Genetics 80 (1990): 65-74.

12. Gupta RB., et al. "Biochemical Basis of Flour Properties in Bread Wheat. II. Changes in Polymeric Protein Formation and Dough/Gluten Properties Associated with the Loss of Low Mr or High Mr Glutenin Subunits". Journal of Cereal Science 21 (1995):103-116.

13. Hintum TJL and Elings A. "Assessment of glutenin and phenotypic diversity of Syrian durum wheat landraces in relation to their geographical origin". Euphytica 55 (1991): 209-215.

14. Ivanov P., et al. "Biochemical and technological characteristics of Triticum aestivum lines from two Crosses between high and low bread-making quality cultivars". Cereal Research Communications 26.4 (1998): 455-461.

15. Ivanov P., et al. "Storage Proteins Characterization of a Group of New Bulgarian High Breadmaking Quality Wheat Lines". Cereal Research Communications 26.4 (1998): 447-454.

16. Jackson E.A., et al. "Proposal for combining the classification systems of alleles of Gli-1 and Glu-3 loci in bread wheat (Triticum aestivum L.)". Journal of Genetics and Breeding 50 (1996): 321-336.

17. Jurkovic Z., et al. "The HMW Glutenin Subunit Composition of OS Wheat Cultivars and their Relationship with Bread-Making Quality". Cereal Research Communications 28.3 (2000): 271277.

18. Kolster P., et al. "Additive and epistatic effects of allelic variation at the high molecular weight glutenin subunit loci in determining the bread-making quality of breeding lines of wheat". Euphytica 55 (1991): 277-285.

19. Lafiandra D., et al. "New Data Supporting High Mr Glutenin Subunit 5 as the Determinant of Quality Differences among the Pairs 5+10 vs. 2+12". Journal of Cereal Science 18 (1993): 197205.

20. Laemmli UK. "Cleavage of structural proteins during the assembly of bacteriophage T4". Nature 227 (1970): 680-685. 
21. Lukow OM., et al. "The HMW Glutenin Subunit Composition Of Canadian Wheat Cultivars and their Association with BreadMaking Quality". Journal of the Science of Food and Agriculture 46 (1989): 451-460.

22. Luo C., et al. "Comparison of low- and high molecular weight wheat glutenin allele effects on flour quality". Theoretical and Applied Genetics 102 (2001): 1088-1098.

23. Mao P., et al. "The Composition of High-Molecular Weight Glutenin Subunits of Bread Wheat Germplasms and Their Relationship with Bread-Making Quality". Proceedings of $8^{\text {th }}$ International Wheat Genet. Symposium, Beijing, China 2 (1993): 1197-1202.

24. Margiotta B., et al. "Characterization of High Mr subunits of glutenin by combined chromatographic (RP-HPLC) and electrophoretic separations and restriction fragment length polymorphism (RFLP). Analyzes of their encoding genes". Journal of Cereal Science 17 (1993): 221-236.

25. Metakovsky EV., et al. "Gluten Polypeptides as Useful Genetic Markers of Dough Quality in Australian Wheats". Australian Journal of Agricultural Research 41 (1990): 289-306.

26. Nei M. "Analysis of gene diversity in sub divided populations". Proceedings of the National Academy of Sciences of the United States of America 70 (1973): 3321-3323.

27. Nieto-Taladriz MT., et al. "Effect of gliadins and HMW and LMW subunits of glutenin on dough properties in the F6 recombinant inbred lines from a bread wheat cross". Theoretical and Applied Genetics 88 (1994): 81-88.

28. Odenbach $\mathrm{W}$ and Mahgoub El-S. "Relationships between HMW glutenin subunit composition and the sedimentation value in reciprocal sets of inbred backcross lines derived from two winter wheat crosses". Proceedings of $7^{\text {th }}$ International Wheat Genet. Symposium (1988).

29. Payne PI., et al. "Identification of a high- molecular weight subunit of glutenin whose presence correlated with breadmaking quality in wheat of related pedigree". Theoretical and Applied Genetics 55 (1979): 153-159.
30. Payne and Lawrence. "Catalogue of alleles for the complex gene loci, Glu-A1, Glu-B1 and Glu-D1 which code for high-molecular-weight subunit in hexaploid wheat". Cereal Research Communication 11 (1983): 29-35.

31. Payne PI., et al. "The relationship between HMW glutenin subunit composition and the bread making quality of Britishgrown wheat varieties". Journal of the Science of Food and Agriculture 40 (1987): 51-65.

32. Payne PI., et al. "Relationships Between Seed Quality Characteristics and HMW Glutenin Subunit Composition Determined Using Wheats Grown in Spain". Journal of Cereal Science 7 (1988): 229-235.

33. Pumpyanskiy A "Micro method for determining the swelling of flour in acetic acid". V ser. Technological properties of soft wheats". Leningrad Russia (1971): 37-40.

34. Singh NK., et al. "A Simplified SDS-PAGE Procedure for Separating LMW Subunits of Glutenin". Journal of Cereal Science 14 (1991): 203-208.

35. Todorov. "Study on grain storage proteins and their use as genetic markers in wheat breedings". Autor of Dissertation for Doctor of Sciences (2006).

36. Uhlen AK. "The composition of high molecular weight glutenin subunits and their relation to bread-making quality". Norwegian Journal of Agricultural Sciences 4.1 (1990): 1-17.

37. Vasil IK and Anderson OD. "Genetic engineering of wheat gluten". Plant Science 2.8 (1997): 292-297.

38. Weegels PL., et al. "Functional Properties of Wheat Gluten". Journal of Cereal Chemistry 23 (1996): 1-18.

\section{Assets from publication with us}

- Prompt Acknowledgement after receiving the article

- Thorough Double blinded peer review

- Rapid Publication

- Issue of Publication Certificate

- High visibility of your Published work

Website: www.actascientific.com/

Submit Article: www.actascientific.com/submission.php

Email us: editor@actascientific.com

Contact us: +919182824667 